\title{
MAGNITUDE AND OUTCOMES OF ROAD TRAFFIC ACCIDENTS IN A TERTIARY CARE CENTRE
}

\author{
P. Anbalagan', B. Sadeeshkumar², V. Udhayasankar ${ }^{3}$ \\ ${ }^{1}$ Assistant Professor, Department of General Surgery, Government Vellore Medical College, Vellore. \\ ${ }_{2}^{2}$ Assistant Professor, Department of General Surgery, Government Vellore Medical College, Vellore. \\ 3Junior Resident, Department of General Surgery, Government Vellore Medical College, Vellore.
}

\section{ABSTRACT}

\section{BACKGROUND}

Road Traffic Accidents are the eighth leading cause of death. RTAs are the leading cause of death in younger individuals. Every year more than a million people die on the road due to RTAs. Road traffic accident is defined as an incident on a way open to public traffic resulting in one or more persons injured or killed, involving at least one moving vehicle.

Objective of the study is to assess the magnitude and outcomes of road traffic accidents among trauma victims.

\section{MATERIALS AND METHODS}

This was a retrospective study conducted in Government Vellore Medical College Hospital, Vellore by analysing the records of Accident Register and case records for the period of January 2015 to December 2015. Totally, 4231 patients were incorporated in this study.

\section{RESULTS}

A total of 4231 patients were incorporated in this study, of which 3384 (79.98\%) were male and 847 (20.07\%) were female. In this study, highest number of RTAs occurred with two-wheeler riders followed by pillion $(31.01 \%, 23.92 \%)$. Both constitute to nearly $55 \%$. Of all trauma victims admitted the in hospital, 107 (2.53\%) died, $454(10.73 \%)$ survived with long term disability on discharge, 62 (1.46\%) referred and 3608 (85.27\%) survived without long term disability on discharge.

\section{CONCLUSION}

This study was conducted to know the outcome of the patients admitted in our institution and help us to improve the Trauma Care System of our own institution and also to impart the knowledge and practices of road safety measures like appropriate use of pavements by pedestrians and avoiding risky driving behaviours to the community.

\section{KEYWORDS}

Road Traffic Accidents, Outcomes.

HOW TO CITE THIS ARTICLE: Anbalagan P, Sadeeshkumar B, Udhayasankar V. Magnitude and outcomes of road traffic accidents in a tertiary care centre. J. Evolution Med. Dent. Sci. 2017;6(8):609-611, DOI: 10.14260/Jemds/2017/130

\section{BACKGROUND}

Accident is an incident occurring suddenly, unpredictably and unintentionally under unforeseen conditions.[1] Road Traffic Accident is defined as an incident on a way open to public traffic resulting in one or more persons injured or killed, involving at least one moving vehicle. RTAs may be between two or more number of vehicles, between vehicles and pedestrians, between vehicles and animals, or geographical or architectural obstacles.[2]

Road Traffic Accidents Kill nearly 1.2 million people a year and disabling or injuring about 20-50 million people per year globally, a huge global burden and economic loss. ${ }^{[3]}$ The report written by WHO in 2013 showed that more than 1.24 million people die every year as a result of road traffic injuries, making it "the eighth leading cause of death globally, and the leading cause of death for young people aged 15-29".

Financial or Other, Competing Interest: None.

Submission 21-12-2016, Peer Review 13-01-2017,

Acceptance 20-01-2017, Published 25-01-2017.

Corresponding Author:

Dr. P. Anbalagan,

Assistant Professor

Government Vellore Medical College Hospital,

Vellore-632011, Tamilnadu.

E-mail: anbalagan_88chemco@yahoo.com,velloregdr@gmail.com DOI: $10.14260 /$ jemds $/ 2017 / 130$

\section{(c) $(1)$}

RTAs will become the fifth leading cause of death globally by 2030, if the current trend continues.[4] Improved life expectancy along with urbanisation are putting heavy pressure in general as well as mainly on road transport system, in the developing world.[5]

In developing countries, the road traffic related injuries are mainly due to increase in number of vehicles, poor enforcement of traffic safety measures like wearing helmet, lack of knowledge, inadequacy of public health infrastructure.[6]

\section{MATERIALS AND METHODS}

The aim of this study is to assess magnitude and outcome of road traffic accidents among trauma victims. This study conducted as a retrospective study in our institute, Government Vellore Medical College Hospital, Vellore from the period of January 2015 to December 2015. The population included in our study was those who got admitted to our hospital. All victims' case records and accident register were verified and available information prepared as formats for this study. Totally, 4231 patients were included in this study.

\section{RESULTS}

In this study, totally 4231 patients' case records and accident register was analysed.

Sociodemographic Characteristics 
Totally 4231 patients were included in this study. Among them, 3384 (79.98\%) were male and 847 (20.07\%) were female. The mean age of the victims was 25.5. The maximum number of victims were between the age group of 20 to 29 (22.41\%), followed by 30 to 39 years $(18.48 \%)$. The place of residence of victims were mostly rural, 2454 (58.01\%) patients, followed by urban population (41.99\%).

\begin{tabular}{|c|c|c|c|}
\hline $\begin{array}{c}\text { Age } \\
\text { (Years) }\end{array}$ & Male & Female & Total \\
\hline$<10$ & $101(2.98 \%)$ & $22(2.6 \%)$ & $123(2.90 \%)$ \\
\hline $10-19$ & $402(11.88 \%)$ & $84(9.91 \%)$ & $486(11.49 \%)$ \\
\hline $20-29$ & $745(22.02 \%)$ & $203(23.97 \%)$ & $948(22.41 \%)$ \\
\hline $30-39$ & $610(18.03 \%)$ & $172(20.31 \%)$ & $782(18.48 \%)$ \\
\hline $40-49$ & $586(17.32 \%)$ & 147 (17.36\%) & $733(17.32 \%)$ \\
\hline $50-59$ & $513(15.16 \%)$ & $116(13.7 \%)$ & $629(14.87 \%)$ \\
\hline \multirow[t]{2}{*}{$>60$} & 427 (12.61\%) & 103 (12.15\%) & $530(12.53 \%)$ \\
\hline & $3384(79.98 \%)$ & 847 (20.01\%) & 4231 \\
\hline
\end{tabular}

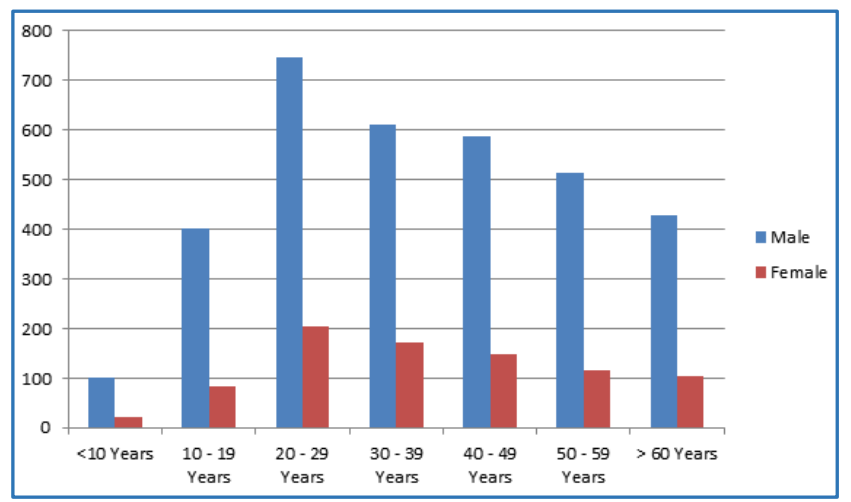

Figure 1. Age and Sex Distribution of Trauma Victims

\begin{tabular}{|c|c|}
\hline Urban & $1777(41.99 \%)$ \\
\hline Rural & $2454(58.01 \%)$ \\
\hline \multicolumn{2}{|c|}{ Place of Residence } \\
\hline
\end{tabular}



Figure 2. Place of Residence of Trauma Victims

\begin{tabular}{|c|c|c|}
\hline Vehicle & Number of Cases & $\mathbf{\%}$ \\
\hline Pedestrian & 592 & 13.99 \\
\hline Bicycle & 106 & 2.51 \\
\hline Two Wheeler Rider & 1312 & 31.01 \\
\hline Two wheeler - Pillion & 1012 & 23.92 \\
\hline
\end{tabular}

\begin{tabular}{|c|c|c|}
\hline Three Wheeler & 349 & 8.25 \\
\hline Four Wheeler & 569 & 13.45 \\
\hline Heavy Motor Vehicles & 291 & 6.87 \\
\hline
\end{tabular}

Table 2. Vehicle Types that caused Road Traffic Accidents and Patient Role at the time of Road Traffic Injury

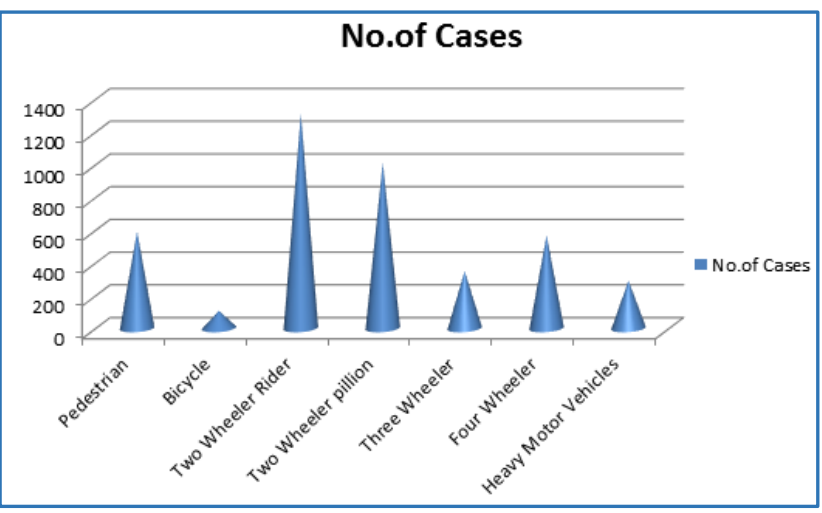

Figure 3. Vehicle Types that caused Road Traffic Accidents and Patient Role at the time of Road Traffic Injury

In this study, highest number of RTA noted in twowheeler riders followed by pillion $(31.01 \%, 23.92 \%)$. Both constitute nearly $55 \%$ of all types of vehicular injuries. This is because our district has more number of middle income people, common mode of transport used by them are two wheelers. This study is contrary to some studies done in urban centres.

\begin{tabular}{|c|c|c|}
\hline Outcome & Frequency & $(\%)$ \\
\hline Survival without longterm disability & 3608 & 85.28 \\
\hline Survival with longterm disability & 454 & 10.73 \\
\hline Referred & 62 & 1.46 \\
\hline Died on Discharge & 107 & 2.53 \\
\hline Total & 4231 & 100 \\
\hline
\end{tabular}

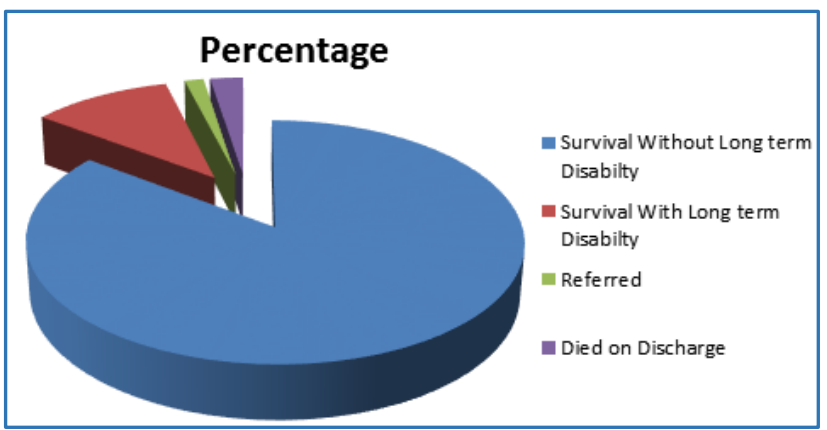

Figure 4. Outcome of Trauma Victims

Of all trauma victims admitted in hospital, 107 (2.53\%) died, $454(10.73 \%)$ survived with long term disability on discharge, 62 (1.46\%) referred and 3608 (85.27\%) survived without long term disability on discharge.

\section{DISCUSSION}

The current study revealed that 2463 (58.21\%) of the victims were in age group between 20-49 years which is consistent with other similar studies.[7-9] This study reveals that more number of victims/sufferers were from economically productive age group which leads to economic loss to their family as well as the nation. The study results shows that 
males were more commonly affected than females. Because males are the main earning members of the family, they are exposed to the road traffic very often than females due to their nature of work.

In this study, it was found that motorcycles were responsible for the majority of road traffic crashes that is consistent with the study conducted on motorcycle injuries as an emerging public health problem in Mwanza City, northwestern Tanzania.[10] This study is contrary to the study conducted in Buganda Medical Centre in Same area.[11]

Perceived Barriers of road safety are the cyclists who are exposed to the dangerous behaviours from motor vehicle drivers and also the increased level of stress when the volume of traffic is high. Pedestrians are exposed to high risk while trying to cross the heavy traffic roads, and also at zebra crossings.

The lack of road safety behaviour, lack of infrastructure tends to cause more no. of road traffic accidents. Lack of infrastructure indicates poor roads, not having the proper signals, not having separate bays for vehicles (bus bay, two wheeler bay). Inadequate driving training and road safety knowledge leads to poor driving skills which in turn increases the road traffic accidents. Carrying bulky loads in the vehicles also leads to increase in road traffic injuries.

There is a need to improve traffic system for users of road to avoid road traffic accidents by reducing the risk of human, environmental, and vehicle causes during three phases of a crash event (Pre-Crash, Crash, Post-Crash). Education on road safety, recruitment of skilled drivers and strengthening the Governmental Traffic Acts is very important to reduce the magnitude of road traffic accidents.

Policies for motorcycle riders, community involvement for road safety, severe punishment for breach of traffic rules on road, sensitisation and mobilisation of proper use of the roads, regular servicing of the cars/motorcycles, restricting use of cell phones while driving will change and reduce the magnitude and occurrence of road traffic accidents in our district.

\section{CONCLUSION}

In our institute, most number of trauma related admissions are due to road traffic accidents. RTA victims were predominantly male and people aged $20-49$ years.
Most of them are from urban areas. Patients from rural areas more commonly presented. Motor vehicle injuries were most common cause of injury. The most common victims are two-wheeler riders and pillion riders.

This study was conducted to know the outcome of the patients admitted in our institution and help us to improve the Trauma Care System of our own institution and also to impart the knowledge and practices of road safety measures like appropriate use of pavements by pedestrians and avoiding risky driving behaviours to the community.

\section{REFERENCES}

[1] Dandona R, Mishra A. Death due to road traffic crashed in Hyderabad city in India: Need for strengthening surveillance. Natl Med J India 2004;17(2):74-9.

[2] Wikipedia: http://en.wikipedia.org/wiki/Traffic_collision.

[3] Peden M, Scurfield R, Sleet D, et al. eds. World report on road traffic injury prevention. Geneva: World Health Organization, 2004.

[4] World Health Organization. Global status report on road safety: supporting a decade of action. 2013.

[5] World Health Organization 1984. Road traffic accidents in developing countries. Technical Report Series No. 73. Geneva, WHO. http://whqlibdoc. who.int/trs/WHO_TRS_703.pdf.

[6] Nantulya VM, Reich MR. The neglected epidemic: road traffic injuries in developing countries. $\mathrm{Br}$ Med J 2002;324(7346):1139-41.

[7] Taye M, Munie T. Trauma registry in Tikur Anbessa Hospital, Addis Ababa, Ethiopia. Ethiop Med J 2003;41(3):221-6.

[8] Osman M, Kebede Y, Anberbir S. Magnitude and pattern of injuries in North Gondar administrative zone. Northwest Ethiopia. Ethiop Med J 2003;41(3): 213-20.

[9] Jha N, Srinivasa DK, Roy G, et al. Epidemiological study of road traffic accident cases: a study from South India. Indian J Community Med 2004;29(1):20-4.

[10] Chalya PL, Mabula JB, Dass RM, et al. Injury characteristics and outcome of road traffic crash victims at Bugando medical centre in Northwestern Tanzania. J Trauma Manag Outcomes 2012;6(1):1. 